\title{
Analysis of the Relationship of Service Quality, Motivation and Destination Image to Destination Loyalty: A Case Study of Wonorejo Mangrove Ecotourism in Surabaya, East Java
}

\author{
Anggi Novita Dewi ${ }^{1}$ and Zainal Abidin ${ }^{1 *}$ \\ ${ }^{1}$ Department of Socio-Economy Fisheries and Marine, Faculty of Fisheries and Marine Sciences, \\ Universitas Brawijaya, Jl. Veteran, Ketawanggede, Lowokwaru, Malang city, East Java 65145, \\ Indonesia
}

*Correspondence :

z_abidin@ub.ac.id

Received : 2020-06-15

Accepted : 2020-08-13

Keywords :

Service quality, Motivation, Destination image, Destination loyalty, Mangrove ecotourism

\begin{abstract}
Surabaya as the capital of East Java Province has a tourism attraction based on mangrove ecosystems namely Wonorejo Mangrove Ecotourism. Interest in the growth of loyalty to the destination depends on service quality, motivation, and destination image. Service quality is the heart of marketing and one of the concepts of loyalty success determines the sustainability of a tourist destination in the future. Motivation is also considered the main driver for traveling. However, this depends on the destination image in the minds of tourists. The purpose of this study was to analyze the direct and indirect relationship between service quality and motivation towards destination loyalty, which is mediated by destination image. From 276 online and offline questionnaires distributed to local tourists who visited or visited the Wonorejo Mangrove Ecotourism in the past years, 182 questionnaires were filled in completely. Data analysis used WarpPLS to examine the relationship of influence between variables. The results showed that service quality and motivation had a positive and significant effect on destination loyalty directly or mediated by destination image. Destination loyalty can be effectively increased by encouraging visitor motivation supported by an increase in destination image because the value of the total influence was at the largest of 0.443 .
\end{abstract}

\section{INTRODUCTION}

Ecotourism is a form of travel to natural areas to conserve the environment and preserve the lives and welfare of local people (Fahrian et al., 2015). Specifically, ecotourism is a development of the tourism concept (Attar et al., 2013). One of the mangrove tourism destinations based on ecotourism is in a city in East Java province, namely the city of Surabaya. Ecotourism that has long been known as mangrove ecotourism in Surabaya city is Wonorejo Mangrove
Ecotourism. In 2010, Wonorejo Mangrove Ecotourism began to publicly open as a tourist attraction. It was managed by the local government, private sector, and the local people. However, the number of visits to Wonorejo Mangrove Ecotourism decreased from 2018 to 2019, from 522,805 people to 391,230 people or there was a decrease of $25.17 \%$. People who visit certain tourist attractions have different purposes, including vacation, sports, business, events, education, and so 
on. Therefore, tourist loyalty needs to be taken seriously by the tourism managers because loyalty is the guarantee of a sustainable tourism business. Improving the quality of tourist attraction is an effort to achieve tourist loyalty as this is a determining factor for tourists' interest in visiting and influencing the number of tourist visits (Hermawan, 2017). Therefore, this study analyzes the relationship between the influence of service quality on destination loyalty and on motivation to destination loyalty directly or indirectly by adding a mediating variable, namely the destination image. The indicators of service quality variable are assurance, responsiveness, reliability, tangible facilities, and empathy (Akroush et al.,
2016). The indicators of the motivational variable are knowledge, physical pleasure, price and health. The indicators of destination image variable are cognitive, unique and affective (Llodra-Riera et al., 2015). Meanwhile, an indicator of the destination loyalty variable is the intention to revisit and recommend it to others (Suhartanto et al., 2018).

\section{METHODOLOGY}

\section{Place and Time}

This research was conducted on February 29-March 152020 at Wonorejo Mangrove Ecotourism (WME) which is located at Jalan Raya Wonorejo 1, Wonorejo, Rungkut sub-district, Surabaya city, East Java (Figure 1).

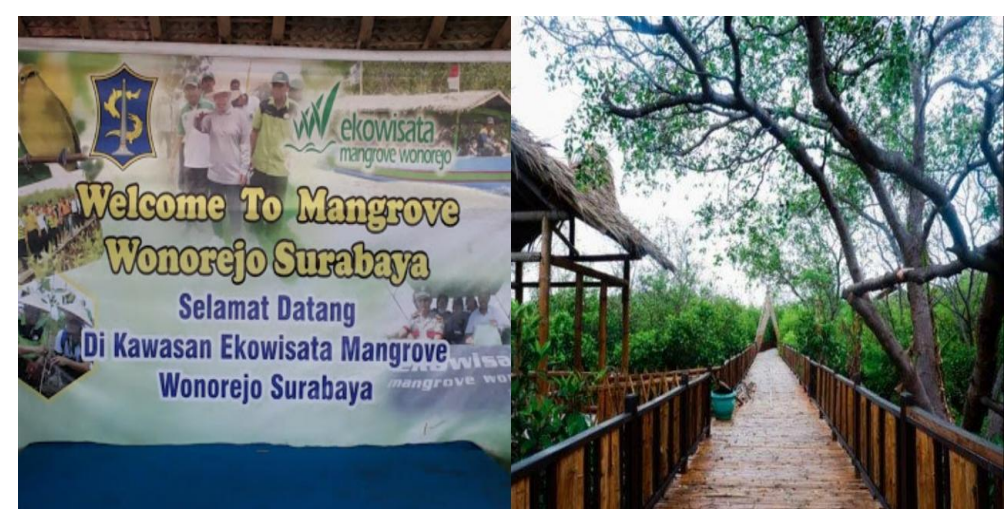

Figure 1. Wonorejo Mangrove Ecotourism.

This location was chosen because Wonorejo Mangrove Ecoutorism is the first mangrove ecotourism in the region and is popular in Surabaya city and its surroundings as a chosen ecotourism destination, especially for urban communities.

\section{Research Material}

The quality of tourism service is the heart of marketing because the quality of tourism service is one of the successes and the central concept of tourism destination loyalty. The quality of tourism service has a relationship with destination loyalty, but it depends on the destination image in the minds of tourists, so the quality of tourism service can affect tourist loyalty through a destination image as a mediator (Akroush et al., 2016). Also, in a tour, both the process of forming a destination image in the minds of tourists and the process of determining a tourist destination can be influenced by tourist motivation (LlodraRiera et al., 2015). Tourist motivation can be considered as the main drive when tourists carry out tourism activities (Yeon et al., 2018). Thus, the tourist motivation in tourism activities is one of the determinants of tourist loyalty. Tourist loyalty can eventually have an impact on the sustainability of tourist attractions (Suhartanto et al., 2018).

According to Permatasari et al. (2017), service quality is a comparison between the desired service and the perception of the service obtained. Quality of service is essential to success in 
destination marketing. Service quality has basic dimensions of SERQUAL (service quality) to determine visitor loyalty. According to Dwiputra (2013), motivation is fundamental in tourists and tourism because motivation is the trigger for the process of travel, even though the motivation is often not realized by tourists. Furthermore, destination image stated by Suwarduki et al. (2016) is attitude, prejudice, imagination and emotional thoughts of individuals and groups towards a tourist attraction, while destination loyalty is a measure of attitude, including the intention to revisit and recommend the destination to others (Permatasari et al., 2017).

There are four hypotheses from this present study, which are:

H1: Service quality has a significant and positive effect on destination loyalty

H2: Service quality has a significant and positive effect on destination loyalty mediated by destination image

H3: Motivation has a significant and positive effect on destination loyalty

H4: Motivation has a significant and positive effect on destination loyalty mediated by destination image

\section{Research Design}

This type of research was explanatory research with a survey research and quantitative approach. Explanatory research has two problem formulations, namely comparative and associative hypotheses. This study used associative problem formulation with asymmetric relationship, namely the relationship between independent and dependent variables (Solimun et al., 2017). One of the methods in explanatory research is survey using census or sampling. Explanatory research with a survey method is a research design with a quantitative approach (Kadji, 2016). Quantitative research is used to test variables, determine the causality of variables, test theories and look for generalizations or predict future results (Salim and Haidir, 2019).

\section{Work Procedures}

Data collection in this study included interviews, observation, documentation, and questionnaires. Interviews were conducted with the tourism managers to get information about the history and profile of Wonorejo Mangrove Ecotourism. Observation was used to observe the conditions around the ecotourism location. Meanwhile, documentation was used to obtain research-related documents, and questionnaires were given to obtain data from tourists who visit the tourist attraction online and offline. The questionnaires used a Likert scale with a score of 1-5 with the criteria of strongly disagree to strongly agree. Those questionnaires were distributed to tourists of Wonorejo Mangrove Ecotourism according to predetermined sample criteria. They were spread to as many as 276 respondents, and 182 were filled by the respondents, to be continued to the data analysis stage. Respondent profiles can be seen in Table 1 .

\section{Data Analysis}

Data analysis in this study used Structural Equation Modeling Warp Partial Least Square (SEM-WarpPLS) developed by Kock (2017). The model used in this study was a statistical model which, according to Solimun et al. (2017) is an effort to simplify a problem into the concept of statistics.

A statistical model that involves the relationship between variables and also the indicator model simultaneously is called the Structural Equation Modeling. The type of relationship between variables in this study is an asymmetric relationship, in which the relationship between these variables is one-way causal flow (recursive model). Meanwhile, the model of indicator variable of this research used a reflective model, except for the formative variable of service quality. Data analysis using SEM does not require many 
assumptions and can be analyzed with a sample that is not too large (Wahyoedi and Saparso, 2019). The minimum sample size in the analysis in SEM is 100 samples (Suwendra, 2018). The descriptive analysis is conducted to interpret the results of the SEM WarpPLS analysis according to the statement of Istijanto (2005) that descriptive analysis transforms raw data into more concise information.

\section{RESULTS AND DISCUSSION}

Mangrove forests in Wonorejo have existed since the Reformation era. However, due to a large number of illegal logging of mangrove trees used as fuels for tofu and coal factories, damage to mangrove forests occurred. This illegal logging then continued until 2008. Therefore, law enforcement and the effort to change mangrove forests into ecotourism can reduce illegal logging and reforest mangrove forests, as well as introduce potential in Wonorejo, Surabaya. For this reason, it is necessary to maintain tourist loyalty to ensure the sustainability of tourism in the future.

Table 1. Respondent profile.

\begin{tabular}{llc}
\hline & Respondent profile. & Percentage (\%) \\
\hline Sex & Male & 35.71 \\
Age (year) & Female & 64.29 \\
& $17-25$ & 66.48 \\
& $26-36$ & 15.93 \\
Marital status & $36-45$ & 8.25 \\
& $>45$ & 9.34 \\
Education level & Single & 68.13 \\
& Married with no children & 6.59 \\
& Married with children & 25.28 \\
& Primary education (SD/MI) & 4.39 \\
& Secondary education (SMP/MTS) & 9.34 \\
Occupation & Secondary education (SMA/SMK/MA) & 61.54 \\
& Diploma & 3.30 \\
& Degree (S1, S2, S3) & 21.43 \\
& Student & 48.35 \\
& Civil servant & 4.39 \\
& Private employee & 24.18 \\
Religion & Entrepreneur & 13.19 \\
& Housewife & 7.69 \\
Income & Household personal assistant & 0.55 \\
& Unemployed & 1.65 \\
Frequency of visits & Moslem & 96.15 \\
& Christian & 3.85 \\
& <Rp.2,500,000 & 64.83 \\
& Rp.2,500,000-Rp.4,000,000 & 20.88 \\
& >Rp.4,000,000 & 14.29 \\
& 1-2 times & 81.87 \\
& 3-4 times & 10.99 \\
& >4 times & 7.14 \\
& Family/relatives/friends & 59.34 \\
& Social media & 37.36 \\
& Originally from Surabaya & 1.65 \\
& supervisor & 0.55 \\
& While studying in the university (ITS) & 1.10 \\
\hline
\end{tabular}

The research data collected were crosschecked through validity and reliability tests (Table 2), all criteria were met and the data were declared valid and 
reliable. Furthermore, based on the SEM Warp-PLS analysis stages, the following analysis results were obtained: a. Evaluation of the Measurement Model (Outer Model)

Table 2. Results of validity and reliability tests.

\begin{tabular}{lllc}
\hline Test & \multicolumn{1}{c}{ Parameter } & \multicolumn{1}{c}{ Rule of Thumb } & Result \\
\hline Validity & Factor Loading Value & $>0.3$ is considered acceptable & Valid \\
Average Variance & $>0.5$ is considered acceptable & Valid \\
Extracted (AVE) & However, if $<0,5$ does not cause a concern, it & \\
is acceptable & Reliability & $\begin{array}{l}\text { Composite Reliability } \\
\text { Coefficients } \\
\text { Cronbach's Alpha } \\
\text { Coefficients }\end{array}$ & $>0.7$ is considered reliable \\
\end{tabular}

b. Evaluation of the Structural Model (Inner Model)

This test was carried out before the interpretation of the results of hypothesis testing, and all criteria were met according to the Goodness of Model Fit (Table 3) which, according to Solimun et al. (2017), is an index or measure of whether or not the relationship between latent variables is related to the assumptions.

Table 3. Model fit and Quality Indices.

\begin{tabular}{|c|c|c|c|}
\hline Model Fit and Quality Indices & Fir Criterion & Analysis Result & Remark \\
\hline Average path coefficient (APC) & $P<0.05$ & $0.348(\mathrm{P}<0.001)$ & Good \\
\hline Average R-squared (ARS) & $\mathrm{P}<0.05$ & $0.597(\mathrm{P}<0.001)$ & Good \\
\hline Average adjusted R-squared (AARS) & $\mathrm{P}<0.05$ & $0.591(\mathrm{P}<0.001)$ & Good \\
\hline Average block VIF (AVIF) & $\begin{array}{c}\text { Acceptable if }<=5, \\
\text { ideally }<=3.3\end{array}$ & 1.860 & Ideal \\
\hline Average full collinearity VIF (AFVIF) & $\begin{array}{c}\text { Acceptable if }<=5, \\
\text { ideally }<=3.3\end{array}$ & 2.336 & Ideal \\
\hline Tenenhaus GoF (GoF) & $\begin{array}{c}\text { small }>=0.1 \\
\text { medium }>=0.25 \\
\text { large }>=0.36\end{array}$ & 0.569 & Ideal \\
\hline Sympson's paradox ratio (SPR) & $\begin{array}{c}\text { Acceptable if }>= \\
0.7, \text { ideally }=1\end{array}$ & 1.000 & Ideal \\
\hline R-squared contribution ratio (RSCR) & $\begin{array}{c}\text { Acceptable if }>= \\
0.9, \text { ideally }=1\end{array}$ & 1.000 & Ideal \\
\hline Statistical suppression ratio (SSR) & $\begin{array}{c}\text { Acceptable if }>= \\
0.7\end{array}$ & 1.000 & Acceptable \\
\hline $\begin{array}{lll}\text { Nonlinear } & \text { bivariate } & \text { causality } \\
\text { direction ratio } & \text { (NLBCDR) } & \end{array}$ & $\begin{array}{c}\text { Acceptable if }>= \\
0.7\end{array}$ & 1.000 & Acceptable \\
\hline
\end{tabular}

c. $\mathrm{R}^{2}$ Value

$\mathrm{R}^{2}$ value was used to measure the variation level of the value change of the independent to the dependent variable. The $\mathrm{R}^{2}$ value (Table 4) obtained is moderate because it is $\geq 0.33$, in accordance with the criteria that $\geq 0.67$ is substantial, $\geq 0.33$ is moderate and $\geq$ 0.19 is weak (Chinn, 1998).

Table 4. $\mathrm{R}^{2}$ value.

\begin{tabular}{cccc}
\hline Variable & $\mathrm{R}^{2}$ & Interpretation & Note \\
\hline Destination Image (X3) & 0.60 & Moderate & $\geq 0.33$ \\
Destination Loyalty (Y) & 0.59 & Moderate & $\geq 0.33$ \\
\hline
\end{tabular}


d. Mediation Test.

1. $\mathrm{X} 1 \rightarrow \mathrm{X} 3 \rightarrow \mathrm{Y}$

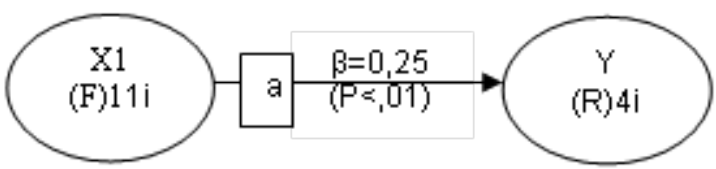

Figure 2. Model without mediation.

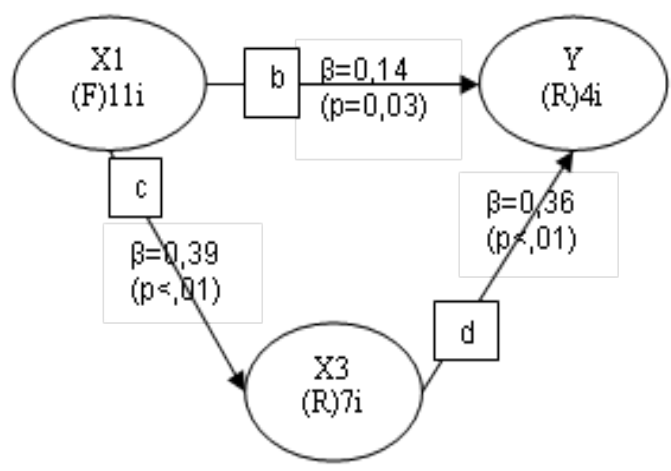

Figure 3. Model with mediation

According to Solimun et al. (2017) if (c), (d) and (b) values are significant and the coefficient (b) is smaller than the coefficient (a), then it is said to be partial mediation. Based on Figures 2 and 3 it is shown that destination image (X3) as a mediator that connects service quality (X1) to destination loyalty (Y) belongs to partial mediation, and Figures 4 and 5 also show that destination image (X3) as a
2. $\mathrm{X} 2 \rightarrow \mathrm{X} 3 \rightarrow \mathrm{Y}$

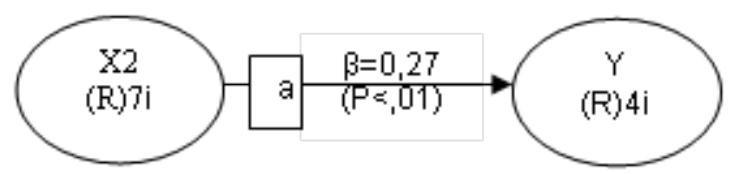

Figure 4. Model without mediation

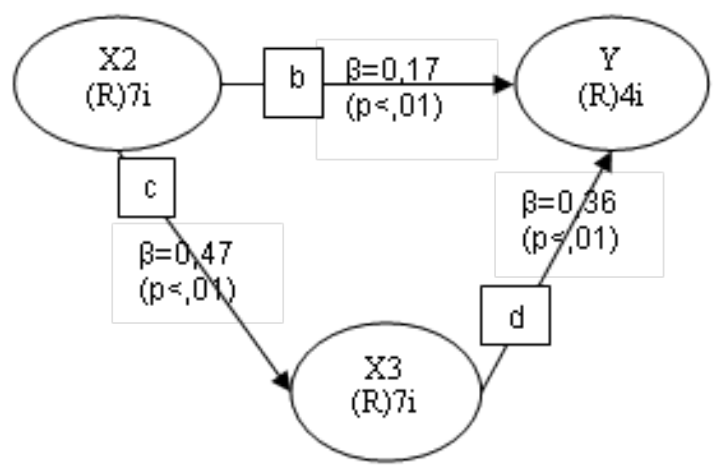

Figure 5. Model with mediation.

mediator which connects motivation (X2) to destination loyalty $(\mathrm{Y})$ belongs to partial mediation.

e. Testing of Effect Effectiveness

Testing of Effect effectiveness was used to compare the effect of direct and indirect relationships and to determine the priority of the effect of effectiveness between variables (Table 5).

Table 5. Direct, indirect, and priority of effect effectiveness between variables.

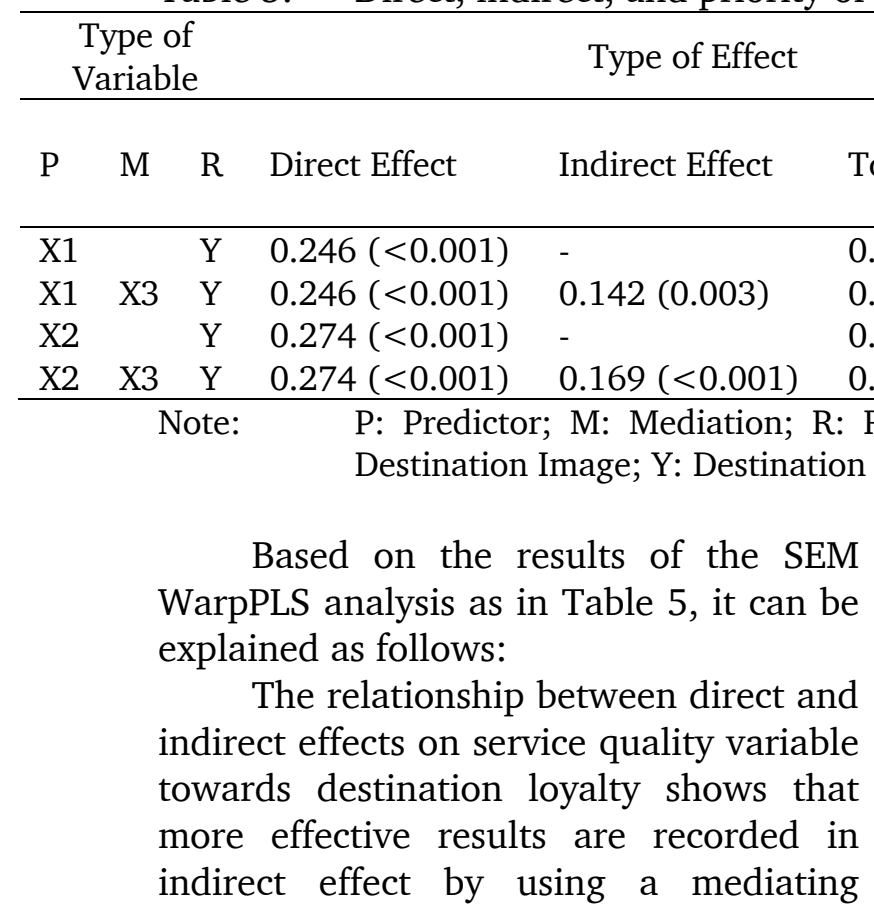

Priority of Effect Effectiveness 
by using a mediating variable, namely destination image. This is because the indirect effect beta coefficient (0.443) is greater than the direct effect beta coefficient (0.274).

The overall effectiveness priority lies in the relationship between the motivation variable and destination loyalty (mediated by the destination image) because the value of the total effect (total beta coefficient) is the largest, standing at 0.443 .

f. Model of Research Results

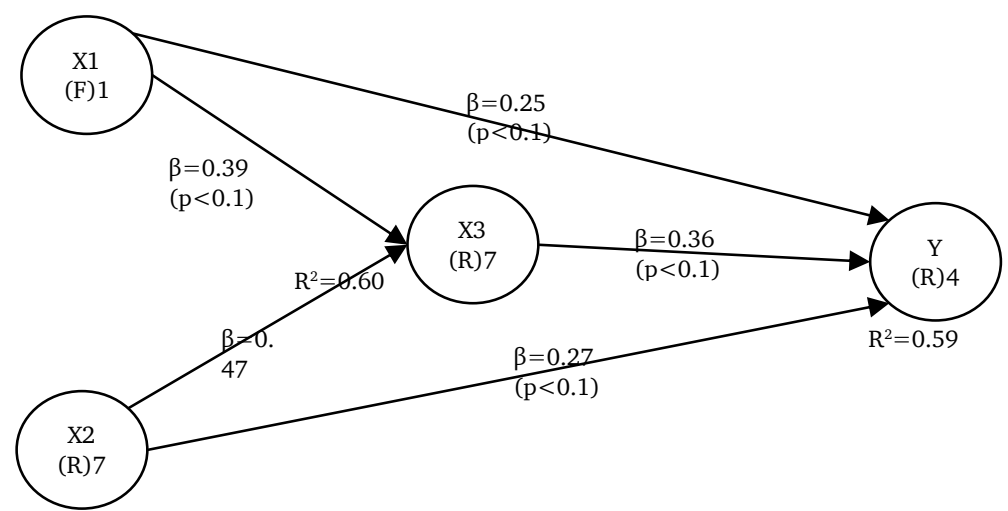

Figure 6. Model of research results.

According to Solimun et al. (2017) p $<0.01$ is said to be highly significant, $\mathrm{P}$ $<0.05$ is said to be significant, $\mathrm{P}<0.10$ is said to be weakly significant. Based on the results of Figure 6 , it can be seen that hypothesis $1(\mathrm{H} 1)$ results in $\mathrm{P}<0.01$ and a beta coefficient of 0.246 , so it can be said that service quality is highly significant and has a positive effect on destination loyalty. The field data show that the dominating service quality in the form of guidance and directions given by Wonorejo Mangrove Ecotourism adds loyalty to that destination. This greatly helps tourists to successfully arrive in the Ecotourism Mangrove Wonorejo location. The results of Hypothesis 2 results are $\mathrm{P}$ $<0.01$ and a beta coefficient of 0.388 , so it can be said that service quality is highly significant and has a positive effect, using a mediating destination image, on destination loyalty.

The field data show that a quality service provided matches with a destination image in the minds of tourists who want to feel a relaxed and comfortable atmosphere during their visit to Wonorejo Mangrove Ecotourism, and it makes the tourists more loyal to the destination. The results of Hypothesis 3 (H3) is $\mathrm{P}<0.01$ and a beta coefficient of 0.274 , so it can be said that motivation is highly significant and has a positive effect on destination loyalty. The tourist motivation to visit Wonorejo Mangrove Ecotourism is to enjoy fresh air because the air condition there is still fresh and free from pollution. This encourages visitors to be more loyal. Meanwhile, the results of Hypothesis 4 (H4) is $\mathrm{P}<0.01$ and a beta coefficient of 0.443 , so it can be said that motivation is highly significant and has a positive effect on destination loyalty, mediated by destination image. The fact that the tourist motivation to visit and enjoy the fresh air is accompanied by the destination image of tourists who want to feel a relaxed and comfortable atmosphere while visiting Wonorejo Mangrove Ecotourism makes tourists want to revisit it in the future. From the overall results, the relationship between variables can form destination loyalty, but Hypothesis 4 has the most dominant relationship in forming destination loyalty because it has the largest beta coefficient value. 
The results of this study can be compared with previous theory and research (Table 6):

Table 6. Comparison of present research with previous theory and research.

\begin{tabular}{lll}
\hline \multicolumn{1}{c}{ Research Results } & \multicolumn{1}{c}{ Position of Theory } & \multicolumn{1}{c}{ Position of Previous Research } \\
\hline $\begin{array}{l}\text { Service quality is } \\
\text { significant to destination } \\
\text { loyalty }\end{array}$ & $\begin{array}{l}\text { Strengthening Marketing theory } \\
\text { by Kloter (1967) }\end{array}$ & $\begin{array}{l}\text { Strengthening the results of previous } \\
\text { research by Permatasari } \text { et al. } \\
\text { (2017). }\end{array}$ \\
\hline $\begin{array}{l}\text { Service quality is } \\
\text { significant to destination } \\
\text { loyalty, mediated by } \\
\text { destination image }\end{array}$ & $\begin{array}{l}\text { Strengthening Marketing theory } \\
\text { by Kloter (1967) and expanding } \\
\text { the theory of consumer behavior } \\
\text { by Mowen and Minor (2002) }\end{array}$ & $\begin{array}{l}\text { Strengthening the results of previous } \\
\text { research by Akroush } \text { et al. (2016). }\end{array}$ \\
\hline $\begin{array}{l}\text { Motivation is significant } \\
\text { to destination loyalty }\end{array}$ & $\begin{array}{l}\text { Extending the theory of } \\
\text { consumer behavior by Mowen } \\
\text { and Minor (2002) }\end{array}$ & $\begin{array}{l}\text { Strengthening the results of previous } \\
\text { research by Suhartanto } \text { et al. } \text { (2018) }\end{array}$ \\
$\begin{array}{l}\text { Motivaton is significant } \\
\text { to destination loyalty, } \\
\text { mediated by destination } \\
\text { image }\end{array}$ & $\begin{array}{l}\text { consumer behavior by Mowen } \\
\text { and Minor (2002) }\end{array}$ & $\begin{array}{l}\text { The results of the study are new } \\
\text { findings that modify the results of } \\
\text { previous research by Suhartanto } \text { et } \\
\text { al. (2018) with a combination of } \\
\text { previous research by Llodra-Riera } \\
\text { et al. (2015) and Akroush } \text { et al. } \\
\text { (2016). }\end{array}$ \\
& &
\end{tabular}

The overall relationship between variables studied shows that service quality and motivation can increase destination loyalty directly or mediated by destination image. The novelty of this research is that motivation has a significant effect on destination loyalty, mediated by destination image. The research results, give practical implications for the development of Wonorejo Mangrove Ecotourism (WME), where the ecotourism managers maintain service quality and fresh air conditions as well as comfort in the WME area as the main motivations for tourists, followed by integrated promotional efforts with marketing strategies to form a destination image. This research can also add insight into marketing in the service sector, especially in tourism marketing because it contributes to strengthening marketing theory and extending consumer behavior theory.

\section{CONCLUSION}

All relationships between variables in this study indicate that the better the tourists' perceptions of service quality, motivation, and destination image, the better tourist loyalty. The tourist loyalty to Wonorejo Mangrove Ecotourism destination can be increased directly by improving service quality and tourist motivation, yet the most effective priority action is to maintain the existence of tourist motivation, followed by efforts to form a destination image.

\section{ACKNOWLEDGMENT}

The authors would like to thank Wonorejo Mangrove Ecotourism, Food Security and Agriculture Department of Surabaya city, and the Faculty of Fisheries and Marine Sciences, Brawijaya University. Also, the authors thank any parties who have helped with the accomplishment of this research.

\section{REFERENCES}

Akroush, M.N., Jraisat, L.E., Kurdieh, D.J., Al-Faouri, R.N. and Qatu, L.T., 2016. Tourism service quality and destination loyalty - the mediating role of destination image from international tourists' perspectives introduction. Tourism Review, 71(1). 
pp.18-44. https://doi.org/10.1108/ TR-11-2014-0057

Attar, M., Hakim, L. and Yanuwiadi, B., 2013. Analisis potensi dan arahan strategi kebijakan pengembangan desa ekowisata di Kecamatan Bumiaji - Kota Batu. Journal of Indonesian Tourism and Development Studies, 1(2), pp.68-78. https:// jitode.ub.ac.id/index.php/jitode/art icle/download/112/108.

Chinn, W.W., 1998. The partial least squares approach for structural equation modelling. Modern methods for business research. Lawrence Erlbaum Associates Publishers.

Dwiputra, R., 2013. Preferensi wisatawan terhadap sarana wisata di kawasan wisata alam erupsi Merapi. Journal of Regional and City Planning, 24(1), pp.35-48. http://dx.doi.org/10.561 4\%2Fjpwk.2013.24.1.3

Fahrian, H.H., Putro, S.P. and Muhammad, F., 2015. Potensi ekowisata di kawasan mangrove, Desa Mororejo, Kabupaten Kendal. Biosaintifika: Journal of Biology \& Biology Education, 7(2), pp.104-111. https://doi.org/10.15294/biosaintif ika.v7i2.3953

Hermawan, H., 2017. Pengaruh daya tarik wisata, keselamatan, dan sarana wisata terhadap kepuasan serta dampaknya terhadap loyalitas wisatawan: studi Community Based Tourism di Gunung Api Purba Nglanggeran. Media Wisata, 15(1), pp.562-577. https://doi.org/10.36 276/mws.v15i1.213

Istijanto, 2005. Riset SDM cara praktis mendeteksi dimensi-dimensi kerja karyawan (1st ed.; A. Purwanto \& Sukoco, eds.). PT Gramedia Pustaka Utama. Jakarta.

Kadji, Y., 2016. Metode penelitian ilmu administrasi (1st ed.; $\mathrm{H}$. Rahmadhani \& H. A. Susanto, eds.). Deepublish CV Budi Utama. Yogyakarta.

Kloter, P., 1967. Marketing management: Analysis planning, and control. Prentice-Hall, Incorporated.
Kock, N., 2017. Common Method Bias: A Full Collinearity Assessment Method for PLS-SEM. In: Latan H., Noonan R. (eds) Partial Least Squares Path Modeling. Springer, Cham. https:// doi.org/10.1007/978-3-319-640693_11

Llodra-Riera, I., Martínez-Ruiz, M.P., Jiménez-Zarco, A.I. and IzquierdoYusta, A., 2015. Assessing the influence of social media on tourists' motivations and image formation of a destination. International Journal of Quality and Service Sciences, 7(4), pp.73-86. https://doi.org/10.1108/ JEA-06-2013-0067

Mowen, J.C. and Minor, M., 2002. Perilaku konsumen. Jakarta: Erlangga, 90.

Permatasari, Y.Y., Murwani, F.D. and Suharto, S.M., 2017. Examining the structural relationships of service quality, destination image, tourist satisfaction and loyalty: an integrated approach. International Journal of Academic Research in Business and Social Sciences, 7(6), pp.367-378. https://doi.org/10.60 07/ijarbss/v7-i6/2990.

Salim, H. and Haidir, 2019. Penelitian pendidikan: metode, pendekatan, dan jenis (1st ed.; Ihlas Satya Azhar, ed.). Kencana Prenadamedia Grup. Jakarta.

Solimun, Fernandes, A.A.R. and Nurjannah, 2017. Metode statistika multivariat pemodelan persamaan struktural (SEM) pendekatan WarpPLS (2nd ed.; Tim UB Press, ed.). UB Press. Malang.

Suhartanto, D., Brien, A., Sumarjan, N. and Wibisono, N., 2018. Examining attraction loyalty formation in creative tourism. International Journal of Quality \& Service Sciences, 10(2), pp.163-175. https://doi.org/ 10.1108/IJQSS-08-2017-0068

Suwarduki, P.R., Yulianto, E. and Mawardi, M.K., 2016. Pengaruh electronic word of mouth terhadap citra destinasi serta dampaknya pada minat dan keputusan 
berkunjung (survei pada followers aktif akun Instagram Indtravel yang telah mengunjungi destinasi wisata di Indonesia). Jurnal Administrasi Bisnis S1 Universitas Brawijaya, 37(2), pp.1-10. http://administrasi bisnis.studentjournal.ub.ac.id/index .php/jab/article/view/1449/1828.

Suwendra, I.W., 2018. Mengintip sarang iblis moral (M. Persada, ed.). Nilacakra. Bandung.

Wahyoedi, S. and Saparso, 2019. Loyalitas nasabah Bank Syariah: studi atas religitas, kualitas layanan, trust dan loyalitas (Wurdiyanto, ed.). Deepublisher CV Budi Utama. Yogyakarta.

Yeon, J.H., Kim, J. and Lee, J., 2018. Effects of tourist destination image and attachment on tourist satisfaction and loyalty. Tourism Management Research, 22(4), pp.959-984. https://doi.org/10.18 604/tmro.2018.22.4.42. 